\title{
Printing Spare Parts through Additive Manufacturing: Legal and Digital Business Challenges
}

\author{
Authors: Rosa Maria Ballardini, Iñigo Flores Ituarte and Eujin Pei
}

\begin{abstract}
Purpose: This paper investigates the technology, business and intellectual property issues surrounding the production of spare parts through Additive Manufacturing (AM) from a digital source. It aims to identify challenges to the growth of the AM spares market and propose suitable solutions.

Methodology: The paper begins with a systematic literature review and theoretical analysis. This is followed by case study research (CSR) through semi-structured interviews, forming the basis of a triangulated, cross-case analysis of empirical data.

Findings: The paper identifies several obstacles to the development of the AM-produced digital spares market. The manufacturing industry will soon be forced to rethink $A M$ as a real manufacturing alternative. Short-term, AM technology has implications for the production of components for legacy systems for which tooling facilities no longer exist. Long-term, AM will be used to produce a wide range of components especially when product and/or service functionality can be increased. To enable companies to navigate current uncertainties in the patent framework (especially the 'repair versus make' doctrine), new IPR strategies could be developed around patenting both complex devices and their individual components, and seeking patent protection for CAD files. Further harmonization of the EU legal framework, the interpretation of claims and the scope of protection offered in the context of spare parts, will also be important.
\end{abstract}

Originality/value: This study pinpoints key issues that need to be addressed within the European AM business environment and the patent system and proposes recommendations for business and legal frameworks to promote the growth of a stable European digital spare parts market.

Keywords: Additive Manufacturing, Spare Parts, Patent Law, Digital Businesses

Paper type: Research paper 


\section{Introduction}

This paper investigates topical business and intellectual property rights (IPR) issues in the context of spare parts produced using Additive Manufacturing (AM) technology. Its intention is to raise awareness of the growing digital spare parts market in Europe, to identify the major business and legal issues that may hinder the growth of this market and to propose solutions to these emerging issues. The integration of digital information systems with AM creates considerable opportunities, but also multiple challenges in terms of the business and legal implications for digital marketplaces for the provision of spares. This study offers novel insights into the development of a stable digital spare parts market that will help companies, legislators, courts and policymakers to better understand the challenges associated with $\mathrm{AM}$, the digitalization and servitization of manufacturing operations and IPR.

Developments in AM technology have the potential to effect fundamental shifts in society (Steenhuis and Pretorius, 2017). AM-digitized supply chains enable new, decentralized, operations-centric business models, which will become a competitive advantage in the 21st century manufacturing industry. The prediction is that a more generic model that includes highly automated digital fabrication systems while also taking a human-centric approach into account to complement current supply chain models (i.e. make-to-stock, make-to-order and engineer-toorder; Holmström et al., 2014). AM has huge potential for helping manufacturers to compete in today's turbulent business environment (Rylands et al., 2016), especially in the area of aftersales service logistics (Eyers and Potter, 2015; Knofius et al., 2016).

Before these shifts in manufacturing business models can take place, however, key technical, business and legal issues must be overcome. To understand the barriers to AM adoption and, thus, to companies' ability to define a clear roadmap for decentralized manufacturing, it is important to examine AM's current position as an alternative to conventional manufacturing, including its technological and operational shortcomings. IPR, i.e. the legal tool that links innovation to the marketplace, also plays a crucial role in supporting new business opportunities for AM-enabled services. Indeed, all these elements (technological, business and IPR-related factors) are interdependent, and must therefore be addressed at the same time to provide a comprehensive understanding of the AM phenomenon.

To date, the question of whether $\mathrm{AM}$ is ready to be integrated as a manufacturing alternative in the service business models of Original Equipment Manufacturers (OEMs) remains open. The technological and operational shortcomings of AM technology have yet to be addressed. Moreover, IPR legal frameworks, if not well calibrated, could hinder rather than promote the development of AM due to its inherent association with the digitalization of manufacturing operations. Although AM technology has the potential to affect all fields of IP law, this paper focuses on patent law in particular. In the context of patent law as it applies to AMproduced spare parts, controversies may arise when the patent on a product that is subject to 'repair' via AM-produced spare parts is seen to be in conflict with claims of IPR ownership of the spare parts. In other words, the key question concerns the conditions in which it is lawful to impede third party 'repairs' of patent-protected products under current interpretations of patent infringement doctrines in Europe. Under current patent law, this question remains open. These 
patent-related challenges must be addressed, as continuing uncertainty could hinder the growth, or even the creation, of a stable digital spare parts market in Europe.

The paper begins with a literature review and theoretical analysis to explore the factors currently influencing manufacturing industries in Europe in their adoption of digital manufacturing and digital spare parts. The theoretical analysis highlights several gaps in the literature, showing that there is little research on the business and patent-related factors that could influence the growth of an AM-produced digital spare parts market in Europe. This is mostly due to the fact that AM-produced spare parts are a relatively recent technological development (Robert K. Yin, 2013), meaning that very little empirical data on the digital spare parts market is yet available.

The study then reports on empirical data gathered from qualitative case study research. In analysing the cases included, we take a holistic approach to exploring the variables influencing the AM-produced digital spare parts market, considering them in their contemporary context. This approach allows us to gain new insights into the shortcomings of the current service market for AM-produced digital spare parts and the related patent framework (in keeping with the 'exploratory' approach to case study research), (Eisenhardt, 1989; Meredith, 1998). It also enables us to develop a comprehensive description of the phenomenon ("descriptive" case study) (Meredith et al., 1989). Finally, it allows us to develop novel and potentially more workable business and legal solutions to foster and accelerate the development of a European digital spare parts market in the context of AM technology.

\section{Digital Spare Parts and Patent Law: Theoretical Framework}

The theoretical framework maps the existing literature on AM-produced digital spare parts, focusing on business and patent law frameworks. This analysis enables us to examine the status quo, consolidate the research findings established thus far, and identify gaps in the literature.

\subsection{Digital Spare Parts and Online Libraries}

Spare parts play an important role in most manufacturing businesses, accounting for up to $45 \%$ of total gross profit and approximately $24 \%$ of revenue (Bacchetti et al., 2012). Currently, spare parts businesses are affected by three main issues (Dekker et al., 1998):

(1) Availability: spares are often not readily available when needed, which can result in a detrimental knock-on effect that affects the reliability of products and services;

(2) Cost: spare parts and tools are stored as physical inventory, which can contribute to increased costs for companies;

(3) Time: producing a single spare part can be time-consuming if tooling is required, which has a negative impact on operational reliability in terms of machine downtime. 
Traditional methods of manufacturing have high upfront costs and are dominated by economies of scale, while AM can support just-in-time (JIT) manufacturing. JIT manufacturing reduces operational costs and delivery times, improving access to spare components (Kretzschmar et al., 2018). AM can also enable manufacturing businesses to produce spare parts, product upgrades and retrofits in a more geographically distributed manner (Manenti, 2014).

In an industrial context, research has shown that digital spare parts make it easier to share product information on the internet (Khajavi et al., 2014), monitor distribution and optimise the production process ( $\mathrm{Li}$ et al., 2016). At a consumer market level, digital businesses such as Turbosquid, GrabCAD, Thingiverse, 3D Warehouse and many others operate as open source libraries of 3D models (Ballardini et al., 2016). The physical parts represented in these online libraries are usually low value components such as plastic gadgets, adaptors, sockets and buttons. This is changing, however. For instance, files for several machine components and (non-critical) spare parts for the McDonnell Douglas (now Boeing) F-18 Super Hornet jet fighter are now also publicly available, and can be produced using AM. The Boeing Company currently holds a patent for a system that will allow aircraft parts to be produced via AM on demand, reducing both the cost and the time involved in ordering replacement components. The system includes a virtual library of parts, a database of technical information and a parts management system (Koreis, 2017), and will reduce the extent to which aircraft service bureaus and maintenance teams have to rely on physical stockpiles of inventory that require manpower and storage space.

Currently, research and innovation projects are investigating novel ways of monetizing service businesses based on AM-produced digital spare parts (VTT, 2016). In the business models of such service businesses, the geometric data for a component to be replaced (i.e. the computer-aided design or 'CAD') is saved in a digital file and then transferred to the manufacturing service to be produced on demand through AM, usually close to the end-user's premises. In this model, digital inventories can be connected to digital marketplaces, linking the needs of end-users to the digital supply chain. This facilitates the implementation of novel business concepts such as digital marketplaces, the supply of digital spare parts, the cocreation of product retrofits or upgrades, mass-customization and e-commerce business activities.
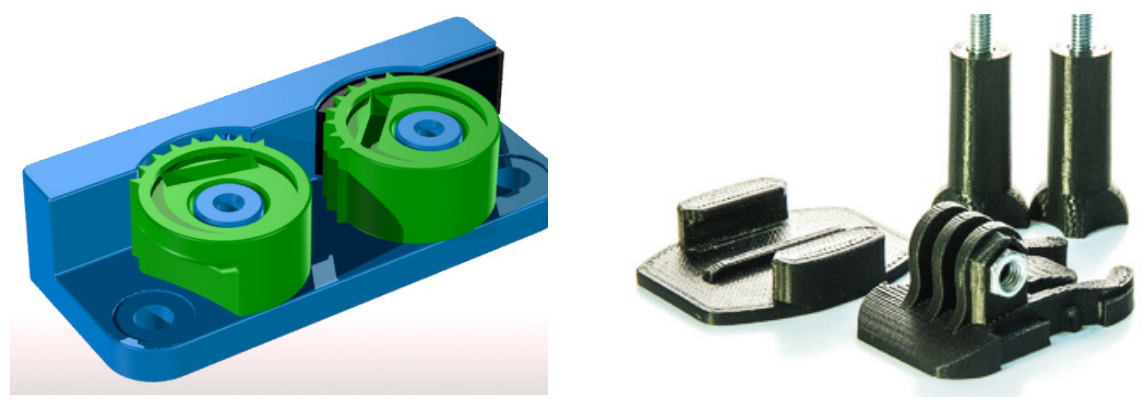
Figure 1. Examples of digital spare parts for automobiles, machine elements and commercial devices. From left to right: (a) guiding element for a Zcorp z650 printer (Robert, 2017) and (b) GoPro camera mount spares (Omeraldi, 2015).

Figure 1 shows two examples of spare parts that can be downloaded and produced using inexpensive AM equipment, the cited repositories include repairs for vehicle parts, machine elements and consumer products respectively. However, business models for AMproduced spare parts services are still at a developmental stage, as is AM technology itself. This means that, currently, there are still many barriers to the adoption of AM technology, including issues with productivity, the availability of materials, part repeatability and manufacturing consistency (Conner et al., 2014). Technological developments are crucial to enabling the integration of AM technology with existing supply chains, a necessary step in the transition to digital spare parts (Flores Ituarte et al., 2016).

\subsection{Patent Infringement and 'Repairing' in Patent Law}

\subsubsection{The Context of Patent Law and Patent Infringement in Europe}

Patent rights enable the right owner to prevent others from 'making, using, selling, placing on the market, offering, importing or storing' a protected invention. ${ }^{1}$ Third parties repairing patent-protected products with digital spare parts could risk infringing upon the IPR of patent holders, as this 'repair' might include carrying out one of the prohibited activities outlined above. For example, in order to repair a protected product by producing a spare part, it might be necessary to 'make' a part of the invention. It should be noted that infringement can occur only if the repairs are carried out for commercial purposes; private use is exempt from patent infringement in most European jurisdictions (Ballardini and Lee, 2017). It should also be clarified that this paper focuses on primary markets for spares (i.e. markets for the production and sale of new products components), as opposed to secondary markets (i.e. markets for the resale or further transfer of used, original components. The legal issues related to the transfer of original components are, in fact, slightly different to those addressed in this paper (see Mineko Mohri, 2010).

European patent law operates in a complex, multi-level system consisting of national and regional patent laws. The European Patent Convention (EPC) ${ }^{2}$ has largely harmonized European patent law at the procedural and pre-grant stages, while leaving post-grant litigation activities related to infringement, as well as exceptions and limitations to infringements, to national jurisdictions. As such, European Member States are free to decide for themselves on the core doctrinal elements of patent infringement such as equivalents for direct infringement or the subjective requirements for indirect infringement actions, as well as the scope of exceptions and limitations to patent rights.

\footnotetext{
${ }_{1}^{1}$ Agreement of a Unified Patent Court (UPC), [2013] C 175/1, Art 25.

${ }^{2}$ Convention on the Grant of European Patents of 5 October 1973 (European Patent Convention).
} 
National laws in relation to post-grant patent matters were stipulated by the Convention for the European patent for the common market, also known as the Community Patent Convention (CPC). ${ }^{3}$ Although it never entered into force, the CPC provided a template that many European Member States incorporated into their own national patent legislation. A more recent (and ongoing) post-grant patent law harmonization effort in the European context is the EU Unitary Patent Package, an initiative for the creation of a new Unitary Patent (UP) that will make it possible to receive patent protection in all EU Member States by submitting a single request to the European Patent Office. The Unitary Patent Package will also see the creation of a Unified Patent Court (UPC), which will offer a cost-effective option for patent enforcement and dispute settlement across Europe (Callens and Granata, 2013; McDonagh, 2016). ${ }^{4}$

Both the CPC and the UPC Agreements recognise two types of patent infringement (direct and indirect) and two types of liability (primary and secondary). Direct infringement occurs when someone 'makes, sells, places on the market, uses, offers, imports or stores' a patented invention without authorization. In the context of producing spare parts for patented products, the relevant infringing act is 'making' the patented invention. Indirect infringement occurs when 'means that relate to an essential element of the invention are supplied on the national territory (where the patent has effect) to any person other than a party entitled to exploit the patented invention with the knowledge that such means will be used in an infringing product or method' (Ballardini et al., 2015). Thus, in the case of spare parts, if someone knowingly supplies an unauthorised third party with an unpatented part related to an essential element of a patented product, the patentee might be able to assert indirect infringement.

\subsubsection{Making, Repairing and the Context of Digital Spare Parts}

The concept of the statutory right of 'making' a patented invention has generally been interpreted in similar ways in most European countries. For product patents (the focus of our study) 'making' could include producing a product from raw materials, transforming a product's form or function, assembling a product from simple or complex pieces, or even building a product from an assembly kit. The making of a new product can take place even if the parts used in its creation are second-hand or refurbished. A product does not need to be completely finished in order to infringe. An unfinished product is generally considered to be 'made' when it has progressed far enough in the manufacturing process to include, either literally or equivalently, the inventive elements covered by the patent claim. The manufacturing method and the quantity in which the product is produced is irrelevant so far as infringement of a product patent is concerned (Norrgård, M. 2009).

\footnotetext{
${ }^{3}$ 76/76/EEC: Convention for the European patent for the common market (Community Patent Convention).

${ }^{4}$ 89/695/EEC: Agreement relating to Community patents - Done at Luxembourg on 15 December 1989, Official Journal L 401, 30/12/1989 P. 0001 - 0027, Article 25 (originally number 29); Regulation (EU) $1260 / 2012$ Implementing enhanced cooperation in the area of the creation of unitary patent protection with regards to the application translation arrangement, Published OJEU L361/89-92; Agreement on a Unified Patent Court, Document no 16351/12. (11.Jan 2013).
} 
Patent rights are state-granted monopolies, designed to promote technological progress and calibrated to benefit society as a whole (Edwin C Hettinger, 1989). This is why the exclusive rights granted by patents are subject to exceptions and limitations that balance the interests of right holders and users (Lee, 2007). In the context of product patents and spare parts, the most relevant limitation relates to the principle of exhaustion, which exists in all EU countries, although in different forms (such as through statutory provisions or case law interpretations). The doctrine of exhaustion limits the extent to which patent holders can enforce their rights on a sold patented product after it has entered the market with the right holder's consent. It should be noted that in Europe, the concept of 'regional exhaustion' also applies, based on the EU principle of the free movement of goods as enshrined in Art. 28 (ex. 30) of the EC Treaty. When the UPC Agreement and the UP Regulation enter into force, the patent exhaustion doctrine will, for the first time, be governed by statutory EU law. ${ }^{5}$

In Europe, the patent exhaustion doctrine originated from the European Court of Justice (CJEU) ruling in Centrafarm v. Sterling Drug, ${ }^{6}$ which spelt out two key elements required for the exhaustion of patent rights in a sold product to take place: (1) the placing of the patented product on the market in the European Economic Area (EEA) (2) by or with the consent of the patent holder.

Putting the product on the market means that the patent holder transfers the right to dispose of the goods embodying the patented invention to a third party, allowing the patent holder to realize the economic value of the patent right. In other words, the first authorized sale of a product by the patent holder (or a licensee) results in the exhaustion of patent rights for the sold product. Consequently, purchasers of the sold product may use, resell and import the product in the territories where the exhaustion principle applies without additional consent from the patentee (Haapanen, 2017). For example, if someone (a commercial entity) buys a bicycle which is patent-protected, they have the right to use, resell and import that bike without obtaining permission from the right holder. However, because the permitted acts following exhaustion cover only the particular product sold (i.e. that particular copy of the bike), making (as well as selling or offering for sale) a new product (i.e. a new copy of the bike) is not allowed.

The exhaustion principle also covers the loan and ordinary repair of the product. 'Ordinary repair' of a product sold is allowed only insofar as such repair does not equate to 'making' the invention. The distinction between 'making' versus 'repairing', however, is not straightforward. Although making copies of someone else's patented invention is a clear infringement, it is not clear whether and to what extent purchasing a patented item and subsequently modifying or repairing it is allowed. The question is: does repairing a patented product by replacing parts of it qualify as 'ordinary' repair, or 'remaking' the invention and, as such, infringing upon the rights of the patentee? Under what conditions is replacing individual unpatented parts, one at a time, whether the same part repeatedly or different parts successively, allowed? In other words, how can we draw the line between legitimate repair and repair that counts as infringing? The difficulties in distinguishing between repairing and making,

\footnotetext{
${ }^{5}$ See Article 29 of the Agreement on Unified Patent Court and Article 6 of the Unitary Patent Regulation.

${ }^{6}$ Centrafarm v. Sterling Drug, Inc. (C-15/74) 19742 C.M.L.R. 480.
} 
become more complex when it comes to patented products that need to be refilled, giving third parties the opportunity to provide substitutes for parts of the patented invention alongside refills.

Generally speaking, there is no real agreement on the interpretation of 'repair' in the EU. The notion of 'repair' is not mentioned in any patent statute in Europe and national case law on the issue is scarce. The concept of permissible 'repair' is interpreted with slight differences in different EU member states. In fact, although the act of replicating a patented invention is clearly forbidden by the patent law of all EU countries, different European courts have disagreed on whether and to what extent producing, transforming, assembling or even building a product is legitimate (i.e. whether it counts as 'ordinary' repair or not).

From the point of view of legal principles, in Europe, patentees are not considered to have a monopoly on the right to repair their patented products. ${ }^{7}$ At the same time, however, some courts have specifically stated that there is no such right as the right to repair as such. On the other hand, ,courts have also affirmed that the question of whether an act constitutes 'repairing' or 'making' a patented invention is a matter of 'fact and degree'. This was, for instance, affirmed in the UK decision in the Schütz $v$ Werit case, which involved replacement parts (namely plastic bottles) for patent-protected intermediate bulk containers (IBCs). This interpretation highlights the need to find a balance between different considerations, including 'the need to protect the patentee's monopoly while not stifling reasonable competition'. ${ }^{8}$ Another essential question is whether the function of the patented invention is embodied by the component subject to repair; in other words, whether 'when the part in question is removed, what is left embodies the whole of the inventive concept of the claims'. In this particular case, the court found that the bottle was relatively subsidiary to the patented article, because the IBC cage still embodied the whole of the inventive concept covered by the patent even after the bottle was removed. As such, the addition of a new bottle to an empty IBC cage did not fall within the scope of the patent's claims and no infringement occurred. Another relevant recent case from Germany, where infringement was found, is the Trommeleinheit (drum unit) case, ${ }^{9}$ which involved Canon K.K., a patent owner and manufacturer of copying machines, printers and their respective toner cartridges. In the toner market, Canon has to compete with companies that reuse toner cartridges by replacing the photosensitive drum with a new drum. Canon filed a law suit that claimed direct infringement of its patent on a photosensitive drum unit, as well as a cartridge and an electrophotographic image-forming apparatus encompassing the drum unit. The defendants distributed recycled printer cartridges which could be used instead of the cartridges manufactured and distributed by the plaintiff. Both the Düsseldorf District Court and the Düsseldorf Court of Appeal found that the defendant, by substituting the drum, had engaged

\footnotetext{
${ }^{7}$ See, for instance, United Wire Ltd $v$ Screen Repair Services (Scotland) Ltd [2001] F.S.R. $24 \mathrm{HL}$, Schütz (UK) Ltd v Werit (UK) Ltd (Rev 1) [2013] UKSC 16 (13 March 2013), BGH 14.07.1970, GRUR 1971, 78, 80 Diarähmchen V, BGH 17.07.2012, docket no. X ZR 97/11 Palettenbehälter II, available in German at: http://juris.bundesgerichtshof.de/cgibin/rechtsprechung/document.py?Gericht=bgh\&Art=en\&sid=3c6d49f845dcefd695bb195c4e4722bb\&nr=6 1447\&pos=0\&anz=1. See the English translation in IIC, Pallet Container II (Palettenbehälter II) (2013) 44 at 351-360, 351, DOI 10.1007/s40319-013-0044-3.

${ }^{8}$ See Schütz (UK) Ltd v Werit (UK) Ltd (Rev 1) [2013] UKSC 16 (13 March 2013).

${ }^{9}$ See also Trommeleinheit [Drum Unit] - court docket: X ZR 55/16, GRUR-Prax 2018, 50 of the $24^{\text {th }}$ of October 2017.
} 
in an act equivalent to reconstruction (i.e. an act of infringement). The key reason for this was that the technical effect of the invention was embodied in the element that was replaced.

Generally speaking, the factors that are usually taken into consideration by European courts when deciding on issues of 'making' as opposed to 'repairing' patented products include:

(1) Whether and to what extent the technical effects of the invention are embodied by the component replaced. In other words, does the part in question form part of the inventive character of the product and, as such, reflect the technical effects of the patent?

(2) The need for repair of the product (estimated with respect to the working life of the device). For instance, was the spare part in question expected to be replaced during the normal working life of the product?

(3) The extent of the repair compared with the manufacturing process of the original product. Do the measures taken to repair the patented product maintain its identity as it was entered into the market, or do they equate to creating a new product?

(4) The extent to which the repaired part competes with the original parts.

All of these factors must be considered while also balancing the interests of all parties involved, including patent holders, users and third parties. It is commonly agreed that courts should also make every effort to consider both the interests of the inventor and implications for trade and the economy. Finally, it is important to mention that issues of repairing versus making in patent law frequently arise in suits against the manufacturers or sellers of replacement parts that allege secondary liability, for instance by asserting that the sale (or offer for sale) of a replacement part constitutes indirect infringement (Holder and Schmidt, 2006; Mohri, 2010).

Many questions concerning patent law and infringement actions in the context of $A M$ remain unanswered. For example, while it is clear that someone using a 3D printer to fabricate a protected device for commercial purposes without authorization would be 'making' that device, the legal implications are ambiguous when only some parts of a device are produced using AM, as it is difficult to determine whether this should be classified as repairing or making. Only once a claim has been properly examined is it possible to determine whether such conduct amounts to infringement. Some general points should be clarified, however.

For instance, the relationship in terms of IPR protection between the digital CAD file and the patented object represented by the file is unclear in existing legislation (Holbrook, 2017). The extent to which IPR can be applied to protect the valuable information contained within CAD files is also unclear. The question of whether sharing a digital representation of a patentprotected object over the internet could be considered as either direct or indirect patent infringement is even more uncertain. It is likewise unclear whether the CAD file of a protected object is capable of qualifying as 'means' or even an 'essential element' for the purpose of indirect patent infringement (Ballardini and Norrgård, 2016; Ballardini et al., 2017). The situation becomes even more complicated when one considers that CAD files allow data to be easily modified, further blurring the line between making and repairing. It is difficult to determine how much modification is allowed before it could be considered patent infringement (Wilbanks, 2012). While many companies are already using AM-produced digital spares, there is a clear 
gap in the literature and legal framework in relation to how the important questions outlined above should be addressed. An empirical analysis through case studies is needed to better understand the challenges of the digitalization and servitization of manufacturing operations and the role of patents in the AM-produced digital spare parts business. Developing a deeper understanding of these issues is necessary in order to help companies, legislators and policymakers to build a roadmap for a stable AM-produced digital spare parts market in Europe.

\section{Challenges and Opportunities: Empirical Analysis}

\subsection{Empirical Study}

The theoretical analysis highlighted several gaps in the literature and identified questions about business and legal frameworks in need of further investigation. In order to deepen and contextualise our understanding of the challenges facing the AM-produced digital spare parts market, we conducted an empirical study in the form of case study research (Robert K. Yin, 2011). Case study analysis was chosen because an in-depth investigation was needed to provide a holistic understanding of the issue being studied, and because the digital spare parts market is a 'contemporary phenomenon within a real-life context' (Robert K. Yin, 2013). In other words, an interpretative and 'existential' enquiry (Meredith, 1998), focused on participants' subjective experiences and understanding, was required in order to examine the extent to which developing a sustainable market for AM-produced digital spare parts in Europe is economically and legally feasible.

The cases that formed the basis of our study were selected from representative companies operating in the field. A 'multiple' case study was conducted, both to increase external validity (Voss et al., 2002), and because more than one case was available (Stake, 1995). The need to develop a comprehensive and descriptive theory of the phenomenon of AMproduced digital spare parts also justified the use of a 'descriptive' case study (Meredith et al., 1989).

\subsubsection{Selection of Respondents}

Empirical data was gathered from seven semi-structured interviews with representatives from relevant companies. Companies were identified through multiple sources, namely business and legal journals, advice from experts, webpages, prominent databases (including the International Standard Industry Classification (ISIC) and the Statistical Classification of Economic Activities in the European Communities (NACE)) and national industry classification systems from the countries under investigation. An information-oriented technique was used to select the subjects of the study.

The companies were chosen for their representativeness with respect to the study's overall research objective, and with a view to maximizing what could be learned in the time available for the study. Respondents were chosen from private companies working in different 
areas of relevance to the study. In particular, we interviewed right holders from several relevant industries, users, and experts in IP law (i.e. internal and external company lawyers and patent agencies). Table 1 provides details of each case and respondent.

Table 1 - Details of case units and respondents

\begin{tabular}{|c|c|c|c|}
\hline Cases \# / date & Company Description & $\begin{array}{l}\text { Respondents' Position/s in } \\
\text { the Company }\end{array}$ & Cluster \\
\hline $\begin{array}{l}\text { Case } 1 \\
23.05 .2017\end{array}$ & $\begin{array}{l}\text { OEM which manufactures and } \\
\text { services power equipment for } \\
\text { the marine and energy } \\
\text { industry }\end{array}$ & $\begin{array}{l}\text { 1- Director of IAM (Intellectual } \\
\text { Asset Management) }\end{array}$ & Right holders \\
\hline $\begin{array}{l}\text { Case } 2 / \\
04.05 .2017\end{array}$ & $\begin{array}{l}\text { OEM which provides process } \\
\text { technologies and services for } \\
\text { metals and mining, industrial } \\
\text { water treatment, alternative } \\
\text { energy and chemical } \\
\text { industries }\end{array}$ & 1- IPR manager & Right holders \\
\hline $\begin{array}{lrl}\text { Case } \quad 3 & \text { / } \\
22.05 .2017\end{array}$ & $\begin{array}{l}\text { OEM which provides cargo } \\
\text { and load handling solutions }\end{array}$ & $\begin{array}{l}\text { 1- Vice president of } \\
\text { digitalization }\end{array}$ & Right holders \\
\hline $\begin{array}{l}\text { Case } 4 \text { / } \\
04.05 .2017\end{array}$ & $\begin{array}{l}\text { OEM which develops and } \\
\text { markets systems, equipment } \\
\text { and services for the railway } \\
\text { sector }\end{array}$ & $\begin{array}{l}\text { 1- Digital, sales and customer } \\
\text { service innovation; } \\
\text { program manager }\end{array}$ & Right holders \\
\hline $\begin{array}{l}\text { Case } 5 / \\
13.06 .2017\end{array}$ & $\begin{array}{l}\text { Service organization } \\
\text { specializing in } \\
\text { IPR }\end{array}$ & $\begin{array}{l}\text { 1- European patent attorney } \\
\text { \& senior IP advisor; 2- } \\
\text { European patent attorney \& } \\
\text { partner; 3- European patent } \\
\text { attorney \& senior IP Advisor; } \\
\text { 4- IPR specialist }\end{array}$ & Experts in IP law \\
\hline $\begin{array}{lrl}\text { Case } & 6 & \text { / } \\
15.06 .2017\end{array}$ & $\begin{array}{l}\text { Service organization } \\
\text { specializing in IPR }\end{array}$ & $\begin{array}{l}\text { 1- IP lawyer; 2- European } \\
\text { patent attorney }\end{array}$ & Experts in IP law \\
\hline $\begin{array}{lrl}\text { Case } \quad 7 & \text { / } \\
13.06 .2017 & \end{array}$ & $\begin{array}{l}\text { Service organization } \\
\text { specializing in legal services, } \\
\text { including IPR }\end{array}$ & 1- senior associate & Experts in IP law \\
\hline
\end{tabular}

Because the applications of digital spare parts are not limited to any one industry, the companies were selected from several fields, namely the transportation, maritime, and energy and process industries. The strategic research council (SRC) has identified these industry 
sectors, among others, as strategic areas for the implementation of advanced manufacturing technologies based on AM (AM-motion, 2017).

The companies were chosen because of their work in areas relevant to the study, and the individual respondents because they were experts on the research topic. The size of the companies and their geographical areas of operation were not considered as selection criteria. Table 2 provides the rationale for including the selected cases.

Table 2 - Rationale for case selection

\begin{tabular}{|c|c|}
\hline Cases \# / date & Relevance to the Study \\
\hline $\begin{array}{lr}\text { Case } & 1 \\
23.05 .2017\end{array}$ & $\begin{array}{l}\text { The company manufactures and services power sources and other equipment in the marine and } \\
\text { energy industries. The expert selected for interview oversees the company's intellectual asset } \\
\text { management, playing a key role in developing best practice and strategies for the management } \\
\text { and use of the company's intangibles, including trade secrets, patents, trademarks, unique } \\
\text { knowledge, technologies and processes. The company has been testing the use of AM in final } \\
\text { production for two to three years already. In this context, AM for spare parts has been a crucial } \\
\text { area of investigation for multiple reasons, including issues related to the availability of spares and } \\
\text { sustainable production. As such, this case contributed to the study by providing knowledge about } \\
\text { important applications of AM to spare parts production, as well as shedding light on effective } \\
\text { business and IPR strategies (including licensing strategies) to foster the development of the digital } \\
\text { spare parts market. }\end{array}$ \\
\hline $\begin{array}{l}\text { Case } 2 \text { / } \\
04.05 .2017\end{array}$ & $\begin{array}{l}\text { This company develops and commercialises mineral and metal processing technologies, including } \\
\text { filters, pumps, compressors, heat exchangers, structural elements, etc. AM's ability to produce } \\
\text { lighter, more resource-efficient products is of great interest to the company. For this reason, the } \\
\text { company has recently established an expert group to carry out a pilot project to develop strategies } \\
\text { (including IPR-related strategies) for the adoption of AM into spare parts production. The expert } \\
\text { chosen for interview is in charge of IPR management within the company and has been involved } \\
\text { in the formulation of new strategies to obtain value for IPR in service operations utilizing AM } \\
\text { technology. The company is relevant to the study as it was able to provide concrete business and } \\
\text { IPR strategies related to specific applications of AM-produced spare parts in industries that } \\
\text { produce highly complex products that include valuable components. }\end{array}$ \\
\hline $\begin{array}{l}\text { Case } 3 \\
22.05 .2017\end{array}$ & $\begin{array}{l}\text { The company develops and commercializes cargo and load handling solutions. The expert } \\
\text { selected for interview oversees the development of digital manufacturing technologies and } \\
\text { manages funding for R\&D strategies to support AM technology. The company's current strategy is } \\
\text { to create product differentiation and speed up the industrialization cycle of digital technologies. } \\
\text { Their core interest in AM technology is related to developing disruptive supply chain models. This } \\
\text { strategy is highly relevant to the phenomenon under study in that it focuses on using AM to } \\
\text { manufacture spare parts for plastic and metallic devices in order to optimise part procurement and } \\
\text { retrofit legacy systems. }\end{array}$ \\
\hline $\begin{array}{l}\text { Case 4 / } \\
04.05 .2017\end{array}$ & $\begin{array}{l}\text { This railway services company has identified AM technology as one of the key drivers of the } \\
\text { digitalization of manufacturing in its business. The company believes that, once the local } \\
\text { production of spare parts becomes technically and economically feasible, AM technology will } \\
\text { improve the efficiency of its global logistics. This will have a radical effect on the company's } \\
\text { business models and operations. The respondent is responsible for the company's digitalization } \\
\text { strategy, which includes the development of AM to produce spare parts on demand and } \\
\text { complement traditional methods of manufacturing. The expert has been involved in the } \\
\text { development of e-commerce channels for spare parts delivery and has led several R\&D-driven } \\
\text { initiatives to productize business cases based on AM technologies. As such, the inclusion of this } \\
\text { case added value by providing insight into the business of AM-produced spare parts and its }\end{array}$ \\
\hline
\end{tabular}




\begin{tabular}{|c|c|}
\hline & associated logistics issues. \\
\hline $\begin{array}{l}\text { Case 5/ } \\
13.06 .2017\end{array}$ & $\begin{array}{l}\text { The company has been advising companies on IPR procurement, prosecution and strategy in } \\
\text { relation to patent protection for spare parts for a long time. Its industry expertise spans mechanical } \\
\text { engineering, electrical and electronic engineering, chemicals, pharmaceuticals and biotechnology. } \\
\text { Lately, due to increased demand from clients for advice on formulating IPR strategies in the } \\
\text { context of AM (in general) and AM-produced spares (in particular), the company is in the process } \\
\text { of developing suitable strategies. For this reason, it has created an ad hoc internal working group } \\
\text { to discuss IPR protection in the context of AM-produced digital spares. The experts interviewed } \\
\text { are part of this ad hoc group. The group also includes members of prominent organizations that } \\
\text { develop policy and legislation in the area of technology and IPR. In this context, the experts } \\
\text { interviewed are currently involved in discussing IPR strategies and possible new legislation related } \\
\text { to digitalization and patent law. The company represented a very relevant case for the study } \\
\text { because the experts interviewed are not only well aware of the current system when it comes to } \\
\text { protecting and enforcing IPR in the spare parts industry, but also industry leaders in terms of } \\
\text { developing IPR solutions in the area of AM and digital spare parts. In addition, this particular group } \\
\text { of experts added additional value to the study because they had inside knowledge of ongoing } \\
\text { policy discussions around the topic and, thus, were able to provide insights into the development } \\
\text { of novel policy solutions to cope with the challenges of AM. }\end{array}$ \\
\hline $\begin{array}{l}\text { Case } 6 \\
15.06 .2017\end{array}$ & $\begin{array}{l}\text { The company has been advising companies on IPR procurement, enforcement and strategy in } \\
\text { relation to patent protection for spare parts for a long time. It has experience in patent filing and } \\
\text { prosecution in most manufacturing industries at the European level, as well as in several national } \\
\text { jurisdictions. The company has considerable experience in advising clients on IPR strategies for } \\
\text { spare parts and is well aware of the strategies that different industries might use to protect and } \\
\text { secure freedom to operate in the spare parts business. Additionally, the company markets itself as } \\
\text { an expert in the field of IPR and technological innovation, including digitalization. As such, it has } \\
\text { recently experienced an increase in demand for consultancy work related to IPR strategies in the } \\
\text { field of AM, with a particular emphasis on the spare parts business. The group of experts } \\
\text { interviewed have already developed and tested some strategies in this area and, thus, were able } \\
\text { to present these novel strategies, identify areas where further research is needed and contribute } \\
\text { valuable insights into the challenges of European patent law in the context of digital spare parts. }\end{array}$ \\
\hline $\begin{array}{l}\text { Case } 7 \\
13.06 .2017\end{array}$ & $\begin{array}{l}\text { The company is amongst the biggest European law firms, with multiple branches and experts in } \\
\text { many legal fields. The expert interviewed represents the IPR division, which is one of the firm's } \\
\text { strengths. The company and the expert selected for interview both have considerable experience } \\
\text { in patent prosecution and litigation, especially in complex technological areas including emergent } \\
\text { technologies. As such, the expert was able to provide relevant information on areas where } \\
\text { possible controversies are likely to arise, point out aspects of the law that need further } \\
\text { development, and make suggestions as to the strategies companies could adopt in order to } \\
\text { navigate current challenges. }\end{array}$ \\
\hline
\end{tabular}

\subsubsection{Interview Protocol, Data Collection, Research Questions and Analysis}

Studying the phenomenon of AM-produced digital spare parts from the point of view of business and patent frameworks requires consulting multiple data sources to enable triangulation. As such, the study gathered evidence from two main sources: interviews and documents. The documents examined were field notes; business reports; publicly available information on the use of AM in companies' businesses; companies' documents on the use of IPR to protect both physical and digital spares; company-owned patents (on entire devices and on spares); European legislation in the area of IPR and spares (in both digital and physical form); publicly available records of court cases from the European Patent Office (EPO), the Court of Justice of the European Union (CJEU) and national European jurisdictions; and company policies concerning IPR and AM technology and business. 
In addition, observations (for instance of participating companies' production, marketing and legal departments) and examinations of participating companies' archives, were also included as evidence sources to improve the validity and reliability of the study. In order to understand the overall impact of AM technology on European business and legal frameworks, variables such as the participating companies' relationships with external suppliers and buyers were investigated both directly, through the interviews, and indirectly, by consulting companies' publicly available records.

The study used a semi-structured interview protocol, in which questions were grouped into two main categories: $(A)$ technology and business-related questions and $(B)$ patent-related questions (refer to Appendix 1: Interview Protocol for a full list of questions). The research questions posed to the companies are summarized in Table 3.

Table 3 - Summary of the scope of the research questions included in the interview protocol. See Appendix 1: Interview Protocol for more details

\begin{tabular}{|l|l|}
\hline Category & Description \\
\hline $\begin{array}{l}\text { (A) Technology and business- } \\
\text { related research questions: }\end{array}$ & $\begin{array}{l}\text { - General and specific research questions related to AM's current status as a } \\
\text { manufacturing alternative, including its technological and operational } \\
\text { shortcomings in the context of spare parts applications, and the extent to } \\
\text { which it is currently used by companies. } \\
\text { - Specific business-related questions related to the possibilities and challenges } \\
\text { involved in making AM technologies a mainstream manufacturing alternative } \\
\text { for service businesses. }\end{array}$ \\
\hline $\begin{array}{l}\text { (B) Patent-related research } \\
\text { questions: }\end{array}$ & $\begin{array}{l}\text { - Specific questions on patents and AM, especially on the challenges that the } \\
\text { 'repair versus make' doctrine in European patent law might pose to the } \\
\text { development of the AM-produced spare parts market in terms of protection } \\
\text { and enforcement. } \\
\text { Questions related to potential solutions to the problems identified in relation to } \\
\text { the 'repair versus make' doctrine. }\end{array}$ \\
\hline
\end{tabular}

The respondents were asked to answer the research questions from the perspective of their company, and also based on their extensive knowledge of the field. The semi-structured nature of the interviews meant that the questions were taken as starting points for further discussion. The respondents were free to propose solutions or provide other insights, as well as to corroborate evidence obtained from other sources not included in the interview protocol. This interactive approach to data collection increased the depth of the data gathered. Moreover, Interviewing multiple people from the same organization allowed us to triangulate their ideas, which helped in obtaining objective and reliable results (Patton, 1987). Overall, the case studies generated new understandings rather than simply answering one or two specific questions, providing a rich corpus of material for the in-depth data analysis.

All companies were consulted at least three times in accordance with the following protocol: (1) initial phone call or email contact with CEO or in-house experts on the topic being investigated to discuss the scope of the study, present the research questions and gather initial feedback on the company's perception of the issues; (2) visit to the company's premises to conduct semi-structured interviews with a group of in-house experts (the number of experts 
varied from company to company: see Table 1 for further details);. (3) final contact with the company's experts to gather feedback on the researchers' own analysis and interpretation of the respondents' answers, as well as to fill in any gaps. In addition to these three stages, some companies were consulted further (via phone, email or in person) to deepen our understanding of some of the more crucial research questions. Qualitative data were collected on all occasions. All interviews were recorded and transcribed to allow for more detailed analysis. We used pattern-matching techniques based on the two categories of questions (business-related and patent-related) and on the two clusters (right holders and experts in IP law). A draft report was written based on the data obtained from the documents and the interviews. The answers from the interviews and the information collected from the documents are presented together, along with the researchers' own perspectives and analysis. All respondents reviewed the report twice to enable effective triangulation (Meredith, 1998) and improve the construct validity (Voss et al., 2002) of the study.

\subsection{Cross-Case Analysis and Discussion}

It was necessary to anonymise both the experts interviewed and their respective companies, as some participants considered the research topic to be both controversial and confidential. To maintain respondents' anonymity, we adopted the compromise suggested by Yin (Robert K. Yin, 2013, p.196) and presented our results as a cross-case analysis instead of a single-case report. In other words, our report does not present a series of case studies focusing on individual companies, but rather a synthesis of lessons learned that draws on and compares examples from across the cases. This compromise was preferable to simply redacting the names of the companies because a cross-case analysis allows for a more thorough discussion of the research questions under study.

The discussion below is divided into two main categories that reflect the structure of the interview protocol (see Appendix 1): (1) business-related questions (section 3.2.1) and (2) patent-related questions (3.2.2). Each of these categories includes subsections (A., B. and C. in section 3.2.1 and $A$. and $B$. in section 3.2.2), the selection of which was driven partly by the structure of the interview protocol, and partly by additional insights and information revealed in the course of the study.

\subsubsection{Technology and Business-related Questions}

\section{A. Existing Bottlenecks for the Adoption of AM Technology in Spare Parts Applications}

The empirical study revealed that the adoption of AM for the production of spare parts is particularly relevant in the case of legacy systems, where it can facilitate the replacement, redesign or repair of components for obsolete machines for which tooling facilities no longer exist. At the same time, however, respondents were concerned that if utilized incorrectly, AM could produce parts of an inferior quality that were more expensive to fabricate. Respondents affirmed that the original materials used to produce these legacy parts are standardized (e.g. 
ASTM steels, aluminium alloys, cast irons, moulded polymers etc.) and their manufacturing processes (e.g. subtractive and formative methods) are highly matured. As such, in many cases the use of AM-produced parts is difficult to justify. For example, case 1 reported that some of their competitors have attempted to use AM to produce propulsion components such as propellers. These companies have experienced serious difficulties due to the low maturity of the technology and the difficulty of integrating it with conventional manufacturing methods.

Our findings generally indicated that although the idea of using AM may appear simple in the context of digital spare parts, the limited scope of AM technology is currently preventing its adoption in several areas (cases 1-4). From the cross-case analysis we concluded that technology push is the predominant factor in advances in AM technology (i.e. AM product and service improvements are being driven by $R \& D$, production and sales, rather than by customer demand for specific technology for the repair of damaged components). In addition, the study revealed that quality assurance and certification have become another barrier to the integration of AM technology into established manufacturing environments (cases 1-4).

Respondents highlighted that there is a legacy of non-digitalized product and component information, and that CAD files often do not exist. Moreover, at times, the original 2D technical drawings can be difficult to locate. At a higher level, another potential problem is the difficulty of changing existing methods of production: the manufacturing industry is generally conservative and relies on conventional methods (case 3). In addition, AM's applications in the spare parts industry are limited in scope, and there is a need to develop a truly global AM manufacturing network (cases 1 and 4). For example, companies sometimes outsource parts of the manufacturing process: in this regard, on a global scale the AM services on offer are limited in comparison to the conventional methods available.

These shortcomings notwithstanding, respondents had high expectations about developing further applications for AM that take full advantage of its benefits (i.e. spare part availability, reductions in cost for low volume production and improvements in lead-time). This is evidenced by the fact that all the companies (cases 1-4) are in the process of integrating AM as a manufacturing method, and the IPR consultants (cases 5-7) have reported a clear increase in consultancy work in this area over the last 2-3 years. Our analysis also shed light on how crucial IPR protection and IP strategies are to creating a sustainable business in the field of digital spare parts (discussed further in section 3.2.2).

\section{B. The Current Use of AM Technology in Spare Parts Applications}

While respondents agreed that the role of $A M$ in production in general, and in the spare parts industry in particular, remains relatively small, all the companies included in the study were in the process of implementing strategies for exploring the use of $A M$ in the coming years. Cases 1 and 2 had already found that $A M$ is useful for repairing valuable components and supplying spare parts that are sold in small quantities. Case 1 had, for instance, already used AM to produce obsolete components for which tooling was no longer available, while repairing valuable components using AM was already an established method in its service business. By this token, the company predicted that in the future, AM would likely be most useful for the production of components that are rarely needed and/or those that currently have very long 
delivery timescales. This observation was corroborated by several of the business strategy documents consulted.

The study identified a trend towards the digitization of existing inventories to develop more flexible and scalable e-commerce platforms within the right-holder service industry. Interviews with cases $1-4$, as well as an examination of the companies' operations through consulting relevant documents, revealed that these cases have already begun formulating business strategies to develop digital spare parts inventories, the main purpose of which can be summarized as:

1) Improving the availability of original spare parts to suppliers and customers by using a digital platform as a single contact point;

2) Facilitating the process of finding product information, including products' $C A D$ files and other technical and non-technical specifications;

3) Improving the pricing and purchasing process through an easy-to-use internet platform;

4) Centralizing digital data on spare parts to provide a more comprehensive view of the company's spare part business.

This finding was triangulated both during the interview, by asking respondents about the perspectives of their company, suppliers and customers on the issue, and by examining the information found in the companies' corporate strategy documents.

Overall, our research revealed that many applications for AM are currently in the testing phase. Some of the respondents mentioned that they already have existing products or spare parts produced using AM that are commercially available and in use (case 1). To continue this trend, businesses should start developing a wide variety of spare parts to diversify their production volume requirements (cases 3 and 4). Finally, both the interviews and the documents consulted pointed to the importance of developing IPR and business strategies, clearly identifying IPR as a central issue for companies to take into account in this context (discussed further in section 3.2.2).

\section{Making AM-produced Spare Parts Mainstream}

Respondents highlighted the need for further technological research on AM, support for innovation policy and the creation of clear business strategies (including IPR strategies) to encourage greater use of $A M$ in spare parts production. The study found that the innovation projects of the OEMs interviewed are usually a combination of (1) technology push and technical feasibility studies that have the objective of improving the efficiency and costeffectiveness of machine or system components and (2) business development plans. Case 1 revealed that the company typically conducts technical feasibility studies through external actors (e.g. consultancy firms, research institutions and public funding for innovation activities), but defines its business development plans internally. This result was supported by observations and documents that ultimately allowed us to generalize this pattern to the operation of other OEMs beyond the cases studied. 
Respondents also emphasised that in their businesses, the availability of spare parts (i.e. how quickly a company can deliver the parts), is crucial in many situations. Case 3 specialises in constantly improving its spare part delivery times, and in this way is able to retain its competitive edge. As such, pricing is often of secondary importance in its business operations (Kennedy et al., 2002). All the cases investigated operate in asset-intensive industries, in which the availability of spare parts like filters, pumps, compressors, heat exchangers and structural elements is crucial to minimising downtime and ensuring the continuity of service operations (Molenaers et al., 2012). In such industries the issue of cost, which in many cases limits AM's applications (Eyers and Potter, 2015), could be easily offset by reduced machine downtime, making $\mathrm{AM}$ a highly competitive manufacturing alternative. However, the study revealed that the digitalization of part inventories and the creation of ecommerce platforms that link to a deployable AM supply chain must be developed further before digital spare parts can become mainstream.

\subsubsection{Patent-related Questions}

\section{A. 'Repairing' in Patent Law and its Implications for AM Development}

The case study analysis confirmed the theoretical analysis' finding that in the European context, the distinction between repairing and making in patent law is unclear. Respondents considered that further developments in AM are likely to increase the importance and possible applications of this doctrine in many industries, increasing the need for clarification. Exactly how to clarify the issues at stake, however, was considered a difficult question to answer.

Cases 1, 5, 6 and 7 have all been directly or indirectly involved in disputes related to the issue of legitimate repair as opposed to illegitimate making. When case 1 tried to develop suitable IPR strategies for protecting its products (including the products' spare parts) and enforcing its IP rights, it found three factors to be particularly challenging: (1) the lack of harmonization in Europe regarding the interpretation of the 'repair versus make' doctrine, (2) the lack of support from national case law to help in resolving these issues, and (3) the lack of coherence in what little case law there is in this area. Notably, the expert from case 2 affirmed that it was precisely these legal uncertainties that had led the company to decide not to start infringement actions against or negotiations with third parties producing allegedly infringing products (spares), which may have led to a loss of revenues linked to alleged free-riding by these third parties. This confirms the concern, highlighted in the theoretical background, that legal uncertainties could impede the development of a sustainable digital spare parts market.

Although all respondents acknowledged this lack of clarity, most agreed that there is some common ground in the way that the 'repair versus make' doctrine has been interpreted across Europe. On this basis, most respondents said they would welcome efforts to increase the clarity and uniformity of interpretations by building on current guidelines. Both right holders and IPR experts agreed that a better understanding of the legal rules in this field would benefit all parties involved and encourage the growth of a sustainable digital spare parts market in Europe. Indeed, this view was reflected in many of the documents consulted, especially the court decisions, as well as in the observations of companies' legal departments. One 
respondent disagreed, arguing that 'unless it is possible to find clear evidence that these grey areas in the law are damaging a large proportion of the market, then such grey areas should remain untouched to provide companies with more flexibility to operate' (case 1). This perspective was echoed by the company's business strategies and documents, and by observations of the company's production and marketing departments. These two ways of approaching the issue could be explained by the fact that policymakers and judges (and perhaps even companies' legal departments) tend to have a broader perspective on the effect of legal frameworks, while corporate strategy is often more company-focused and practiceoriented (Fisher and Oberholzer-Gee, 2013).

\section{B. Navigating the Challenges: Possible Solutions}

The study was not limited to elucidating the current status quo, but also aimed at identifying ways in which a more functional legal framework could be developed. Some of the solutions presented below (e.g. B1 and B2) have already been tested by the cases in this study, and as such, respondents were able to provide insights into the efficacy of the solutions from their own experience. One solution (B3) reflects proposals for how to improve the legal system in the future, and as such is less currently applicable. In this last case, the study revealed important insights into the effects that the proposed solution could have on the cases' businesses, as well as on the European spare parts market more generally.

\section{B1. Increasing Patent Activities in the Spare Parts Market}

The study revealed that building a clear and well-structured IPR strategy is crucial for companies that produce complex products that are composed of multiple parts and covered by multiple IPRs. Such a strategy is as important for the protection of AM-produced digital spares as it is for physical spares produced via other manufacturing methods. Cases 1, 2 and 3 have found that holding a patent on a complex product per se does not guarantee sufficient protection to patent holders in the spare parts market, mainly because of the legal uncertainty surrounding the 'repair versus make' doctrine and the principle of patent exhaustion. This finding is supported by the legal framework and existing case law, which suggests that there is no agreement on the interpretation of the 'repair versus make' doctrine in Europe, and that the case law is too scarce, fragmented and inconsistent to add clarity. Moreover, existing judgments show that most European national courts tend to favour legitimate repair rather than finding infringement in cases where third parties have offered replacement parts, unless it is evident that the part embodies the technical effect of an existing patented invention (see the cases discussed in section 2.2.2 above).

Cases 1, 2 and 3 produce complex products that include highly valuable spare parts. All of these companies agreed that in their businesses, protecting entire products via patents is not enough to ensure the protection of valuable spares as well. As such, these companies employ a strategy whereby they patent both the product itself and as many of the product's valuable components as possible. Along the same lines, cases 5 and 6 regularly advise clients (except 
those operating in the pharmaceutical industry, which generally requires a different approach) to follow the same strategy in order to increase business revenues.

Respondents pointed out that in some cases where the actual value of a device lies in its components, a more effective strategy would be to hold patents for the components only, without having a patent on the overall device at all. However, none of the cases investigated were using this strategy, as in their view it is highly industry-specific, and more suitable for companies operating in the electronics and automotive industries (industries which were not represented in our study).

Respondents clarified that the purpose of seeking patent protection for spares is different from the purpose of holding patents on devices. Case 2 stated that their business patents devices to provide additional value to customers: 'we use patents to tell our customers to buy from us because we have a much better device than the others in the market'. Patenting spare parts, on the other hand, is a strategy to 'lock-in' customers to a company's products, as it can limit their ability to fix defects themselves. Cases 1,2 and 3 acknowledged that they give careful consideration to which spares to patent so as to avoid customer dissatisfaction. Case 2 has found on some occasions that having too many patents on spare parts, and thus forcing customers to buy spares from them, led to high levels of customer dissatisfaction and reduced return customers.

Case 6 indicated that when advising clients on whether or not to file patents on both a device and its spares, they consider it essential to conduct a cost assessment to compare the value of the knowledge included in the production of the spares with the time, effort and cost of filing patents on them. This insight arose from the firm's experience of several of their patent applications for spares being rejected on the grounds that they were unclear, because the general context or host device was missing from the application. This finding was triangulated by examining business and IPR strategy documents (including granted and pending patent applications) and patent databases (e.g. EPO). These data sources indicated that a relatively high number of patent applications for spares are rejected. ${ }^{10}$ They also revealed that bringing direct infringement actions on the grounds that some parts of a patented product have been replaced is not a good strategy. To successfully protect their IPR, companies should adopt other strategies instead: seeking IPR protection for both devices and their spare parts was found to be the most efficient method. This finding also supports a possible follow-up strategy stemming from the recent German court ruling in the Trommeleinheit case (see section 2.2. above). The ruling hinged on the application of the 'repair versus make' doctrine in the case of a patented drum unit placed on the market as part of a comprehensive device (a toner cartridge), rather than as a stand-alone product. The decision in this case suggests that patent applicants should phrase their claims in such a way as to guarantee that they cover all of an invention's different components, protecting the inventive character of the product at all possible levels.

\section{B2. Patent Infringement Doctrines and Patent Claims for CAD files}

Issues related to direct and indirect patent infringement in the context of AM-produced spare parts generated great interest among respondents. In particular, respondents stressed

\footnotetext{
${ }^{10}$ See, for instance: http://www.epo.org/about-us/annual-reports-statistics/statistics.html.
} 
that AM-produced digital spares add further complexity to the already uncertain situation of patents and spare parts (discussed in section B1). Since AM-produced digital spares are a recent technological development, all the cases were still at an experimental stage in their development of suitable IPR strategies for protecting and enforcing rights in this context. Indeed, the issues identified pose challenges not only in the context of digital spare parts, but for the application of patent doctrines to AM in general.

The cases identified some gaps in the existing legal framework that they had already experienced as problematic in terms of developing IPR strategies for AM and digital spare parts. Firstly, all respondents thought that the question of whether a digital representation of a patented product retains the same level of IPR protection as its patent-protected physical counterpart is unclear under current rules. The relation between the physical and digital versions of a protected object is crucial to the interpretation of the 'repair versus make' doctrine because it defines the scope of the IPR. Some respondents (cases 5 and 7) have already started to develop guidelines advising companies on how to navigate this legal uncertainty. For instance, case 7 highlighted that it is important to clarify whether the technical functions of a patented product are embodied by its digital representation. There was disagreement between respondents, however, as to whether the digital and physical representations of a product should be kept separate for the purposes of IPR protection, with cases 5 and 7 being in favour of such a separation while case 2 held that the digital and physical representation should both attract the same IPR to avoid overly complex licensing schemes. These different ways of approaching the issue will affect the development of companies' IPR strategies related to AMproduced digital spares, and until a court of law clarifies this matter we are likely to see companies following both approaches. This inconsistency could ultimately affect the development of the digital spare parts market as a whole, as it could create complex, inconsistent licensing structures based on whether companies protect only one 'consolidated version' of a device or spare, or separate physical and digital versions.

As regards indirect patent infringement, all respondents agreed that if someone provides a third party with a CAD file of a protected object (e.g. a digital spare part for a protected device) or a critical component, then they could be found liable for indirect infringement. Considering the difficulties for patent owners involved in pursuing cost-effective direct patent infringement actions (especially in view of the uncertainty surrounding the 'repair versus make' doctrine), indirect patent infringement actions could become very valuable in the context of AM. On this front, however, a key unanswered question highlighted by this study is whether CAD files qualify as a 'means' under European patent law. As discussed in the literature review (section 2.2.), for indirect infringement to occur, European patent law requires that the alleged infringer must 'supply (or offer to supply) on the national territory (where the patent has effect) any person other than a party entitled to exploit the patented invention with means related to an essential element of that invention for putting it into effect on the national territory when the third party knows, or should have known, that those means are suitable and intended for putting that invention into effect' (see UPC Agreement, Art. 25). In other words, in order to find indirect infringement in cases where someone has illegitimately provided a third party with a CAD file of a protected object (e.g. a CAD file of a spare part for a protected product), the CAD file must qualify as a 'means' in the eye of the law. If CAD files do not qualify as 'means' then there is no 
possibility of preventing infringements via secondary liability actions in cases relating to the unauthorised supply of CAD files (Mimler, 2013). The problem is that European courts have so far interpreted the concept of 'means' as being physical rather than digital. Although indirect infringement has been found in cases where software was offered (i.e. software has been considered as a 'means'), liability was only established where the source code had been provided on a CD or other physical media. ${ }^{11}$

Although none of the cases have experienced disputes in this area, the study revealed that they have all started to develop business and IPR strategies to tackle this uncertainly. The most interesting strategy is the one under development in cases 2 and 6, which relies on the analogy between the CAD files of patented products and the source code of programs protected by computer-implemented inventions (CII) patents. As already mentioned, software delivered via physical media is currently the only digital thing that has qualified as a 'means' for the purposes of indirect infringement actions. Both CAD files and source code contain a detailed set of instructions in digital form to produce an invention. Therefore, one could argue that if someone provides an unauthorized person with the CAD file of a protected product (perhaps delivered through physical media), they could be found liable for indirect infringement of the product's patent in the same way as they would be had they provided the source code of a program protected by a CII patent.

Some respondents were sceptical about whether this strategy could work in practice, however. Cases 5, 6 and 7 are not advising their clients to rely on this analogy because CII patents have their own distinct legal status and are regulated by different rules in Europe (notably, Art. 52 of the EPC). Such rules may not extend to technologies that do not qualify as computer programmes or software. This discussion sheds light on two additional issues: (1) the legal nature of the CAD file, as a digital dataset that might not count as 'software', and (2) the possibility of claiming protection for CAD files in patent applications. The main concern raised by respondents was that it is unclear how CAD files should be considered from the perspective of patent law. Can a CAD file be considered a technical invention, and therefore qualify as patentable subject matter? Or is it merely information used to produce an invention, and therefore not patentable per se? Could CAD files fall under the ad hoc provision of Article 52 of the EPC for computer programmes? Finally, should it be decided that CAD files do qualify as patentable subject matter, how should the doctrine of exhaustion (and thus the interpretation of the 'repair versus make' doctrine) be applied in a digital context? (Haapanen, 2017).

Under current rules, respondents thought that most national patent offices and courts would not know how to handle patent applications for CAD files, or how to answer questions about the legal nature of CAD data. However, some respondents (cases 2 and 6 ) are in the process of filing patent applications on CAD files of their devices and spares. These companies are testing two different strategies: applying for patent protection for the CAD files themselves, and converting the CAD files into G-code (which counts as a computer programme) and filing a CII patent claim as well. Whether these strategies will succeed remains, at the time of writing, an open question that calls for further research.

\footnotetext{
${ }^{11}$ See for instance BGH decision of 21 August 2012 - Case No. X ZR 33/10- MPEG-2 Video Signal Encoding (MPEG-2-Videosignalcodierung).
} 


\section{B3. Additional Legal Tools to Improve the System}

The study also investigated the potential effects on the EU digital spare parts market of two legal tools that could bring greater clarity to the legal framework surrounding patents, AM and digital spares. The tools tested were: (1) achieving harmonization of the interpretation of the 'repair versus make' doctrine in the EU (through either legislative action or case law interpretation) and (2) limiting the scope of patent protection in the context of spare parts.

In relation to point 1, cases 6 and 7 thought that new EU legislation, such as a Directive or Regulation, would be crucial in establishing some general principles to assist in interpreting the 'repair versus make' doctrine and provide courts with some baseline guidance. This could lead to greater certainty in the patent system, promoting the growth of a European digital spare parts market. At the same time, however, the study suggested that harmonized case law at the national or European level through the forthcoming Unitary Patent Court would be a better option than new legislation, as case law is generally more flexible and thus more suitable for technology-centric areas such as AM that are still in the early stages of development. Generally, it was suggested that harmonization should follow the guidelines outlined thus far in the fragmented national case law on the issue (see section 2.2.).

Another important finding raised by the study is that a lack of clarity in interpretations of the 'repair versus make' doctrine is not necessarily a factor that will impede the growth of the AM-produced digital spare parts market. Greater clarity could benefit new companies entering the spare parts market, and as such could be a good solution in the event that the EU wants to create opportunities for new businesses. It would also be the best option if the EU wishes to keep manufacturing 'in house'. However, any decision to implement this kind of policy must be well grounded in economic or policy justifications and balanced against the interests of 'old players', (companies that have been operating in the industry for a long time). The study found that evidence for these economic or policy justifications is currently lacking.

On point 2, the study found that limiting the scope of patent protection available to devices such that the IPR would not extend to their spare parts could help to clarify the distinction between legitimate repair and unauthorised making. This change would mean that no infringement would occur if only some of a product's components were individually remade. Only case unit 2 considered that this type of proposal might benefit their business operations. At the same time, the respondent highlighted that considerably more research would be needed on the issue. Moreover, the study also pointed to several possible downsides of this suggestion. These included the fact that it would make product patents less effective; that it might push companies to increasingly patent individual components, resulting in potentially harmful effects for third parties due to customers becoming more locked into certain companies' products; and, finally, that it could risk increasing the number of patents, with all the potential problems that would entail for patent tickets, blocking patents and patent trolls in multiple industry sectors (Lemley and Shapiro, 2007).

\section{Conclusions and Future Research}


This study found that AM has huge potential to support the spare parts market. However, the development of AM is still limited by its technological shortcomings, challenges related to the structure of the industry and uncertainties with respect to patent law. The study revealed that a sustainable European market for AM-produced digital spare parts is growing, but that it requires technical, business and legal support to continue to do so. The outcomes of our research suggest that policymakers, regulators and companies must take action if the AMproduced spares market is to reach its full potential.

In terms of AM's implications for industry, the study showed that it has the potential to:

- improve the availability of original spare parts;

- facilitate the process of finding product information, including product CAD data and technical specifications;

- facilitate the pricing and purchasing process through easy-to-use internet platforms and ecommerce services; and

- centralize data on products and spare parts (such as CAD files and meta-information) and improve awareness of companies' spare part businesses.

One of the most important findings to emerge from our research is that OEMs have already begun adopting AM to produce spare parts, product upgrades and retrofits due to its positive impact on spare parts availability. The results of the empirical study further corroborate and extend our existing knowledge by demonstrating how OEMs use AM to replace, redesign and repair components for legacy systems. In terms of AM's current status as a manufacturing alternative, however, our study also revealed that the digitalization of product and tooling inventories is still a challenge due to the legacy of non-digitalized product and component information. In addition, the fact that many companies outsource a large part of their manufacturing represents a bottleneck for AM implementation in the spare parts supply chain. Regarding AM's technological and operational shortcomings, although AM is being deployed as an alternative to conventional manufacturing methods, there is no network of AM service suppliers that can compete with conventional methods on a global scale. In addition, the cost of production is generally higher for AM than for traditional manufacturing methods, mainly due to the high price of raw materials. Ultimately, these shortcomings limit AM's applications, especially as regards the production of large-scale components. AM technology is still in the early stages of development, and must develop further before it can become a fully trusted manufacturing method.

On the topic of patent law, the study found that issues of patent protection and the scope of patent enforcement could create major obstacles to the development of business models in the AM-produced spare parts market. Crucial factors to consider are:

- issues related to the principle of exhaustion of patent rights and interpretations of the so called 'repair versus make' doctrine in European patent law;

- challenges in interpreting traditional patent infringement doctrines in the context of AM and digital representations of spare parts;

- issues related to the nature of CAD files, as well as to protecting CAD files through patent law. 
The study showed that legal uncertainty in this area has been caused by factors such as the lack of harmonization on the 'repair versus make' doctrine in Europe, the limited and contradictory case law, and the fact that the digital element of AM raises questions in the context of patent law, which has traditionally been interpreted only in relation to physical goods and not to digital or virtual representations. Our findings suggest that to navigate the uncertainties surrounding the issue of legitimate repair versus illegitimate making in patent law, new developments must take place outside of the legislative framework, at least in the shortterm.

On this note, new IPR strategies in the digital spare parts market, such as patenting not only complex devices, but also their individual components, as well as filing patent claims for CAD files, could provide a way forward for businesses. These two strategies could lead to both positive and negative consequences for the growth of the digital spare parts market. On the one hand, they could help competitors and third parties to develop a better understanding of whether they are acting legitimately or not (as patents on spare parts could reduce third parties' reliance on interpretations of the ambiguous 'repair versus make' doctrine). Securing protection for digital spares could also increase the use of AM in the production of spares, thereby indirectly encouraging the creation of an AM-produced digital spare parts market. On the other hand, however, these strategies could increase the costs of accessing protected spares. Furthermore, depending on the situation, protecting spare parts may not necessarily reduce reliance on the 'repair versus make' doctrine because, unless all the components of a device are patented, the doctrine will still apply. Indeed, novel interpretations of patent infringement doctrines that are better suited to the digital environment should also be developed, alongside the introduction of new legislation such as new EU Directives or Regulations.

In conclusion, the development of $\mathrm{AM}$ as a manufacturing alternative is now an industrial reality. The reliability and manufacturing capabilities of AM systems have evolved to the extent that the industry has been forced to re-think the technology as a real manufacturing alternative, especially given the current movement towards the digitalization and automation of company supply chains, which are linked to the digitalization and servitization of manufacturing operations. To take full advantage of the opportunities that AM offers, however, it is crucial that the business, technical and legal challenges identified in this study are properly addressed. While the European and global market for AM-produced digital spare parts is still young, it is not too early for businesses, IP right holders, legislators and policymakers to begin preparing themselves for the rise of AM technology in this area.

\section{References}

AM-motion, 2017. A strategic approach to increasing Europe's value proposition for Additive Manufacturing technologies and capabilities [WWW Document]. URL http://www.ammotion.eu/ (accessed 5.18.18).

Bacchetti, A., Plebani, F., Saccani, N., Syntetos, A.A., 2012. Spare Parts Classification and Inventory Management: a Case Study. Salford Bus. Sch. Work. Pap. Ser. 1, 1-32. 
Ballardini, R.M., Lee, N., 2017. The Private and Non-commercial Use Defence Revisited: The Case of 3D Printing Technologies, in: Ballardini, R.M., Norrgård, M., Partanen, J. (Eds.), 3D Printing, Intellectual Property and Innovation - Insights from Law and Technology. Wolter Kluwer, p. 442pp.

Ballardini, R.M., Lindman, J., Ituarte, I.F., 2016. Co-creation, commercialization and intellectual property - challenges with 3D printing. Eur. J. Law Technol. 7, 1-39.

Ballardini, R.M., Norrgård, M., 2016. Digitising patent law: challenges from 3D printing technologies. Eur. Intellect. Prop. Rev. 38, 519-521.

Ballardini, R.M., Norrgård, M., Minssen, T., 2015. Enforcing patents in the era of 3D printing. J. Intellect. Prop. Law Pract. 10, 850-866. doi:10.1093/jiplp/jpv152

Ballardini, R.M., Norrgård, M., Partanen, J., 2017. 3D Printing, Intellectual Property and Innovation. Insights from Law and Technology, First. ed. Kluwer Law International.

Callens, P., Granata, S., 2013. Introduction to the unitary patent and the Unified Patent Court: the (draft) rules of procedure of the Unified Patent Court. Kluver.

Conner, B.P., Manogharan, G.P., Martof, A.N., Rodomsky, L.M., Rodomsky, C.M., Jordan, D.C., Limperos, J.W., 2014. Making sense of 3-D printing: Creating a map of additive manufacturing products and services. Addit. Manuf. 1-4, 64-76. doi:10.1016/j.addma.2014.08.005

Dekker, R., Kleijn, M.J., De Rooij, P.J., 1998. A spare parts stocking policy based on equipment criticality. Int. J. Prod. Econ. 5657, 69-77. doi:10.1016/S0925-5273(97)00050-9

Edwin C Hettinger, 1989. Justifying Intellectual Property. Philos. Public Aff. $18,98$.

Eisenhardt, K.M., 1989. Building theories from case study research. Acad. Manag. Rev. 14, 532-50.

Eyers, D.R., Potter, A.T., 2015. E-commerce channels for additive manufacturing: an exploratory study. J. Manuf. Technol. Manag. 26, 390-411. doi:10.1108/MBE-09-20160047

Fisher, W.W., Oberholzer-Gee, F., 2013. Strategic Management of Intellectual Property: AN INTEGRATED APPROACH. Calif. Manage. Rev. 55, 157-183. doi:10.1525/cmr.2013.55.4.157

Flores Ituarte, I., Khajavi, S.H., Partanen, J., 2016. Challenges to implementing additive manufacturing in globalised production environments. Int. J. Collab. Enterp. 5, 232-247.

Haapanen, A., 2017. Free and Open Source Software Licensing: and the Mystery of Licensor's Patents.

Holbrook, T.R., 2017. Extraterritoriality and Digital Patent Infringement. SSRN Electron. J. doi:10.2139/ssrn.3088027

Holder, N., Schmidt, J., 2006. Indirect Patent Infringement: Latest Developments in Germany. Eur. Intellect. Prop. Rev. 28, 480.

Holmström, J., Partanen, J., 2014. Digital manufacturing-driven transformations of service supply chains for complex products. Supply Chain Manag. An Int. J. 19, 5. doi:10.1108/SCM-10-2013-0387

Karasu, Y., 2013. Renault 9 Water pump pulley - SOLIDWORKS - 3D CAD model - GrabCAD [WWW Document]. URL https://grabcad.com/library/renault-9-water-pump-pulley-1 (accessed 11.28.17). 
Kennedy, W.J., Wayne Patterson, J., Fredendall, L.D., 2002. An overview of recent literature on spare parts inventories. Int. J. Prod. Econ. 76, 201-215. doi:10.1016/S09255273(01)00174-8

Khajavi, S.H., Partanen, J., Holmström, J., 2014. Additive manufacturing in the spare parts supply chain. Comput. Ind. 65, 50-63. doi:10.1016/j.compind.2013.07.008

Knofius, N., van der Heijden, M.C., Zijm, W.H.M., 2016. Selecting parts for additive manufacturing in service logistics. J. Manuf. Technol. Manag. 27, 915-931. doi:10.1108/MBE-09-2016-0047

Koreis, R.R., 2017. Three dimensional printing of parts. US9579850 B2.

Kretzschmar, N., Flores Ituarte, I., Partanen, J., 2018. A decision support system for the validation of metal powder bed-based additive manufacturing applications. Int. J. Adv. Manuf. Technol. 12.

Lee, N., 2007. Toward a Pluralistic Theory on an Efficacious Patent Institution. John Marshall Rev. Intellect. Prop. Law, Vol. 6, p. 224, 2007224.

Lemley, M.A., Shapiro, C., 2007. Patent Holdup and Royalty Stacking. Tex. Law Rev. 85.

Li, Y., Jia, G., Cheng, Y., Hu, Y., 2016. Additive manufacturing technology in spare parts supply chain: a comparative study. Int. J. Prod. Res. 1-18. doi:10.1080/00207543.2016.1231433

Manenti, P., 2014. the Digital Factory: Game Changing Technologies That Will Transform Manufacturing Industry. SCM World, Novemb.

Marcus Norrgård, 2009. Patentin loukkaus. Sanoma Pro Oy.

McDonagh, L., 2016. European Patent Litigation in the Shadow of the Unified Patent Court. Edward Elgar Publishing.

Meredith, J., 1998. Building operations management theory through case and field research. J. Oper. Manag. 16, 441-454. doi:10.1016/S0272-6963(98)00023-0

Meredith, J.R., Raturi, A., Amoako-Gyampah, K., Kaplan, B., 1989. Alternative research paradigms in operations. J. Oper. Manag. 8, 297-326. doi:10.1016/0272-6963(89)90033-8

Mimler, M., 2013. 3D Printing, the Internet and Patent Law - A History Repeating? La Riv. di Dirit. Ind. 62, 352-370.

Mineko Mohri, 2010. Maintenance, Replacement and Recycling - Patentees' Rights in the Aftermarkets. Herbert Utz Verlag GmbH .

Mohri, M., 2010. Maintenance, Replacement and Recycling-Patentees' Rights in the Aftermarkets: Germany, the US and Japan. Herbert Utz Verlag.

Molenaers, A., Baets, H., Pintelon, L., Waeyenbergh, G., 2012. Criticality classification of spare parts: A case study. Int. J. Prod. Econ. 140, 570-578. doi:10.1016/j.ijpe.2011.08.013

Omeraldi, M., 2015. GoPro spare parts by MatteoMeraldi - Thingiverse [WWW Document]. URL https://www.thingiverse.com/thing:1001859 (accessed 11.28.17).

Patton, M.Q., 1987. How to use qualitative methods in evaluation. Sage Publications.

Robert, 2017. Spare part for zcorp z650 3d printer - STL,IronCAD - 3D CAD model - GrabCAD [WWW Document]. 2017. URL https://grabcad.com/library/spare-part-for-zcorp-z650-3dprinter-1 (accessed 11.28.17).

Rylands, B., Böhme, T., Gorkin, R., Fan, J., Birtchnell, T., 2016. The adoption process and 
impact of additive manufacturing on manufacturing systems. J. Manuf. Technol. Manag. 27, 317-360. doi:http://dx.doi.org/10.1108/MRR-09-2015-0216

Stake, R.E., 1995. The art of case study research. Sage.

Steenhuis, H.-J., Pretorius, L., 2017. The additive manufacturing innovation: a range of implications. J. Manuf. Technol. Manag. 28, 122-143. doi:10.1108/JMTM-06-2016-0081

Voss, C., Tsikriktsis, N., Frohlich, M., 2002. Case research in operations management. Int. J. Oper. Prod. Manag. 22, 195-219. doi:10.1108/01443570210414329

VTT, 2016. VTT | Spare parts into data bits - cost efficiency through on demand 3D printing [WWW Document]. URL http://www.vttresearch.com/media/news/spare-parts-into-data-bits (accessed 11.28.17).

Wilbanks, K.B., 2012. The challenges of 3D printing to the repair-reconstruction doctrine in patent law. Geo. Mason Law Rev. 20, 44.

Yin, R.K., 2013. Case Study Research, 5th Revise. ed. SAGE Publications Inc, Thousand Oaks, United States. doi:781452242569

Yin, R.K., 2011. Applications of case study research. Sage. 